\title{
Yield Attributes, Yield, Competitive Ability and Economics of Summer Maize-Legume Intercropping System
}

\author{
Pilli Manasa ${ }^{1}$, Sagar Maitra ${ }^{2}$ and Saurav Barman ${ }^{3}$ \\ ${ }^{1 \& 2}$ Department of Agronomy, M.S. Swaminathan School of Agriculture, Centurion University of Technology and Management, \\ Paralakhemundi-761 211, India \\ ${ }^{3}$ Department of Agricultural Chemistry and Soil Science, M.S. Swaminathan School of Agriculture, Centurion University of \\ Technology and Management, Paralakhemundi-761 211, India
}

"Corresponding author: p.manasa@cutm.ac.in (ORCID ID: 0000-0001-7727-4972)

Paper No. 814

Received: $12-11-2019$

Revised: 04-01-2020

Accepted: 27-02-2020

\begin{abstract}
Maize (Zea mays L.), the queen of cereals, is planted with wide spacing and so it offers the scope of intercropping. Considering the benefits of cereal-legume association, an experiment on maizelegume intercropping system was conducted during summer season of 2018 at Bagusala Farm of M. S. Swaminathan School of Agriculture, Centurion University of Technology and Management, Gajapati district, Odisha. The experiment was laid out in randomized complete block design and the treatments were comprised of ten cropping systems, namely, $\mathrm{T}_{1}$ : sole maize, $\mathrm{T}_{2}$ : sole green gram (Vigna radiata $\mathrm{L}$.), $\mathrm{T}_{3}$ : sole groundnut (Arachis hypogaea $\mathrm{L}$.), $\mathrm{T}_{4}$ : sole black gram (Vigna mungo L.), $\mathrm{T}_{5}$ : maize + greengram $(2: 1), \mathrm{T}_{6}:$ maize + groundnut $(2: 1), \mathrm{T}_{7}:$ maize + blackgram $(2: 1), \mathrm{T}_{8}:$ maize + greengram $(2: 2), \mathrm{T}_{9}:$ maize + groundnut (2:2) and $\mathrm{T}_{10}$ maize +black gram (2:2). Paired row sowing of hybrid maize was done with a spacing of $80 \mathrm{~cm} / 30 \mathrm{~cm} \times 25 \mathrm{~cm}$ in sole maize. Pure stand of legumes i.e. green gram, groundnut and black gram were sown with $30 \mathrm{~cm} \times 10 \mathrm{~cm}$ spacing. As per the treatments, single and double row of intercrops were taken in between two pairs of maize. The result indicated that intercropped legumes improved the yield components of maize and offered some bonus yield. The maximum maize grain yield (5669 $\mathrm{kgha}^{-1}$ ) was noted with sole maize, however, maize equivalent yield of $7609 \mathrm{~kg} \mathrm{ha}^{-1}$ was recorded with maize + groundnut (2:2) and it was followed by maize + black gram with 2:2 ratio (6902 $\left.\mathrm{kg} \mathrm{ha}^{-1}\right)$. In expression of the competition functions, maize + groundnut (2:2) recorded the highest values of area time equivalent ratio (1.70), relative yield total (1.47) and monetary advantage ( $₹ 42002 \mathrm{~kg} \mathrm{ha}^{-1}$ ). The intercropping combination of maize + groundnut (2:2) recorded the highest net return ( $\left.₹ 47954 \mathrm{ha}^{-1}\right)$, with a benefit-cost ratio of 1.00 , but by the treatment maize + black gram with 2:2 ratio registered greater $B: C$ ratio (1.11) with net return of ₹ $45499 \mathrm{ha}^{-1}$.

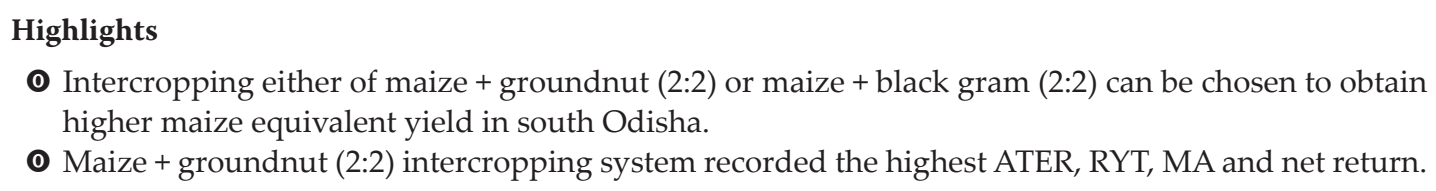

Keywords: Maize, legume, intercropping, yield, competitive ability, economics

Maize (Zea mays L.) is an important cereal in many developed and developing countries of the world and provides maximum share of human food. Since, it is a versatile crop grown across a wide range of agro ecological zones, there is no cereal crop on the earth that has so much yield potential and hence it is popularly called 'queen of cereals'. India produces
21.81 million tonnes of maize from $8.69 \mathrm{~m}$ ha of area with a productivity of $2509 \mathrm{~kg} / \mathrm{ha}$ (Anonymous, 2016). The wider row spacing in maize can be used to grow legumes as intercrop give additional yield. The main concept of intercropping is to get increased total productivity per unit area and time, besides equitable and judicious utilization of land 
resource and farming inputs including labour, with the insurance against crop failure. One of the main reasons for higher yield in intercropping is that the component crops are ableto use growth resources differently, so that when grown together, they complement each other and make better overall use of growth resources than grown, separately (Willey 1979; Maitra et al. 2001). Intercropping of maize and legume is advantageous in many aspects including higher productivity in additive series, $\mathrm{N}$ benefit by maize crop in association and higher monetary return. Legume as an intercrop can increase crop yields and economic benefits of intercropping systems (Mucheru et al. 2010). Maize in association with legumes gave higher total yield and net return (Patra et al. 2000). The impact of maize based intercropping system was not much studied under south Odisha conditions; hence the experimentwas conducted to evaluate the efficiency of summer maize-legume intercropping system.

\section{MATERIALS AND METHODS}

The experiment was conducted at Bagusala farm ( $23^{\circ} 39^{\prime} \mathrm{N}$ latitude, $87^{\circ} 42^{\prime} \mathrm{E}$ longitude) of M. S. Swaminathan School of Agriculture, Centurion University of Technology and Management, Paralakhemundi, Odisha which is situated under typical tropical climatic conditions during the summer season of 2018. The weekly mean maximum and mean minimum temperatures during the crop period ranged from $28.4^{\circ}$ to $45.8^{\circ} \mathrm{C}$ and $14.4^{\circ}$ to $26.5^{\circ} \mathrm{C}$ respectively with an average maximum of $39.8^{\circ} \mathrm{C}$ and minimum of $20.6^{\circ} \mathrm{C}$. The weekly mean relative humidity during crop period ranged from 88.36 percent to 56.9 percent. A rainfall of $69.2 \mathrm{~mm}$ was received the during crop growth the period. The soil was clay loamy in texture, slightly acidic in reaction ( $\mathrm{pH} 6.2)$, low in organic carbon $(0.45 \%)$, available nitrogen, phosphorus and potassium were $78.4,20.6$ and $128.4 \mathrm{~kg}^{-1} \mathrm{ha}^{-1}$ respectively. The recommended doses of fertilizers @ 120:60:60 kg $\mathrm{N}: \mathrm{P}_{2} \mathrm{O}_{5}: \mathrm{K}_{2} \mathrm{Oha}^{-1}$ and 20:50:20 kg N: $\mathrm{P}_{2} \mathrm{O}_{5}: \mathrm{K}_{2} \mathrm{Oha}$ ${ }^{1}$ for sole maize and legumes respectively were applied separately in monoculture. In intercropping situations, the recommended dose of fertilizer for maize (120:60:60 kg N: $\left.\mathrm{P}_{2} \mathrm{O}_{5}: \mathrm{K}_{2} \mathrm{Oha}^{-1}\right)$ was applied. In case of sole maize and maize + legume treatments half dose of nitrogen, entire quality of phosphate and potash were applied as basal dose in each plot, however, all fertilizers were applied as basal to sole legumes. The remaining half of nitrogen was top-dressed to maize and maize + legume plots at knee height stage. The experiment was laid out in a Randomized Complete Block Design (RCBD) comprising ten treatments with 3 replications. Therefore, in each replication there were ten plots of $5.0 \mathrm{~m} \times 4.0 \mathrm{~m}$ size. The treatments were $\mathrm{T}_{1}$ : sole maize, $\mathrm{T}_{2}$ : sole greengram, $\mathrm{T} 3$ : sole groundnut, $\mathrm{T} 4$ : sole blackgram, T5: maize + greengram (2:1), T6: maize + groundnut (2:1), T7: maize + blackgram (2:1), T8: maize + greengram (2:2), T9: maize + groundnut (2:2) and T10 maize + blackgram (2:2). Maize hybrid 'Kaveri' 50 was chosen (120 days) in the experiment and for green gram 'IPM 02-03' (70 days), groundnut 'K6' (125 days) and black gram,'PU 31' (85 days) varieties were selected. Spacing adopted for paired row hybrid maize (under both of sole and intercropping) was $30 \mathrm{~cm} /$ $80 \mathrm{~cm} \times 25 \mathrm{~cm}$, however, pure stand of legume i.e. green gram, groundnut and blackgram were sown with $30 \mathrm{~cm} \times 10 \mathrm{~cm}$ spacing. In intercropped treatments legumes were sown 1 or 2 rows in between two pairs of maize as per the treatment.

\section{RESULTS AND DISCUSSION}

\section{Yield attributes of maize}

The data on yield attributes recorded, viz., number of cobs plant ${ }^{-1}$, number of rows $\mathrm{cob}^{-1}$, number of grains row ${ }^{-1}$, number of grains $\mathrm{cob}^{-1}$, hundred grain weight, grain weight $\mathrm{cob}^{-1}$, and grain weight plant $^{-1}$ were analyzed statistically and presented in Table 1. The data on Number of cobs plant ${ }^{-1}$ showed that there was no significant difference among the treatments, however, $\mathrm{T}_{1}$ : sole maize) and $\mathrm{T}_{9}$ : maize + groundnut (2:2) showed maximum value (1.30). The results are in conformity with the findings of Kheroar and Patra (2013) and Khan et al. (2018). All treatments under study remained statistically at par in registering number of rows per $\mathrm{cob}^{-1}$, but the maximum value (12.8) was noted with $\mathrm{T}_{1}$ (sole maize). Earlier Mandal et al. (2014) noted similar observation. The treatment $\mathrm{T}_{1}$ (sole maize) recorded maximum of number of grains row $^{-1}$ of maize cob (15.9) and it was closely followed by the treatments $\mathrm{T}_{6}$ : maize + groundnut $(2: 1)$ and $\mathrm{T}_{9}$ : maize + groundnut (2:2). Earlier Saleem et al. (2011) obtained similar type of results. Maximum number 
Table 1: Effect of intercropping system on yield attributes of maize

\begin{tabular}{|c|c|c|c|c|c|c|c|}
\hline \multirow[b]{2}{*}{ Treatments } & \multicolumn{7}{|c|}{ Yield attributes of Maize } \\
\hline & $\begin{array}{l}\text { Number of } \\
\text { cobs plant }^{-1}\end{array}$ & $\begin{array}{l}\text { Number of } \\
\text { rows cob }\end{array}$ & $\begin{array}{l}\text { Number of } \\
\text { grains row }^{-1}\end{array}$ & $\begin{array}{l}\text { Number of } \\
\text { grains cob }^{-1}\end{array}$ & $\begin{array}{l}100 \text { grain } \\
\text { Weight (g) }\end{array}$ & $\begin{array}{l}\text { Grain weight } \\
\text { (g) } \operatorname{cob}^{-1}\end{array}$ & $\begin{array}{l}\text { Grain weight } \\
\text { (g) plant }{ }^{-1}\end{array}$ \\
\hline $\mathrm{T}_{5}$ Maize + green gram $(2: 1)$ & 1.26 & 12.2 & 14.7 & 179.3 & 27.41 & 49.2 & 61.92 \\
\hline $\mathrm{T}_{6}$ Maize + groundnut $(2: 1)$ & 1.29 & 12.7 & 15.6 & 198.1 & 27.58 & 54.6 & 70.49 \\
\hline $\mathrm{T}_{9}$ Maize + groundnut $(2: 2)$ & 1.30 & 12.6 & 15.6 & 196.6 & 27.61 & 70.3 & 70.27 \\
\hline $\mathrm{T}_{10}$ Maize + black gram $(2: 2)$ & 1.28 & 12.4 & 15.1 & 187.2 & 27.56 & 51.6 & 67.08 \\
\hline $\mathrm{SEm} \pm$ & 0.03 & 0.49 & 0.65 & 3.41 & 0.68 & 0.91 & 1.62 \\
\hline $\mathrm{CD}(\mathrm{P}=0.05)$ & NS & NS & NS & NS & NS & 2.81 & 4.99 \\
\hline
\end{tabular}

of grains per cob was noticed with the $\mathrm{T}_{1}$ : sole maize (203.52) and it was closely followed by $\mathrm{T}_{6}$ : maize + groundnut (2:1) and $\mathrm{T}_{9}$ : maize + groundnut $(2: 2)$. The results are in conformity with the findings of Rajeshkumar et al. (2018). There was no significant difference among the intercropping systems in enhancement of 100 grain weight of maize cob however, the treatment $\mathrm{T}_{1}$ (sole maize) noted the highest (27.62g) weight of 100 grains. Earlier Jan et al. (2016) also noted non-significant difference in test weight of maize by intercropping system. The treatments differed significantly among themselves in enhancement of grain weight of maize. Highest grain weight $\mathrm{cob}^{-1}(56.21 \mathrm{~g})$ was noticed with $\mathrm{T}_{1}$ : sole maize and the treatment was significantly superior to $\mathrm{T}_{5}$ : maize + green gram $(2: 1), \mathrm{T}_{7}$ : maize + black gram (2:1), $\mathrm{T}_{8}$ : maize + green gram (2:2) and $\mathrm{T}_{10}$ : maize + black gram (2:2). However, sole maize $\left(\mathrm{T}_{1}\right)$ was statistically at par with the treatments $\mathrm{T}_{6}$ : maize + groundnut $(2: 1)$ and $\mathrm{T}_{9}$ : maize + groundnut (2:2) in increasing of grain weight of maize cobs. Grain weight plant $^{-1}$ was significantly influenced by sole maize and other intercropping system .Sole maize $\left(\mathrm{T}_{1}\right)$ produced maximum grain weight plant $^{-1}$ (73.07g) which was statistically at par with $\mathrm{T}_{6}$ : maize + groundnut $(2: 1)$ and $\mathrm{T}_{9}$ : maize + groundnut (2:2). But the treatment $T_{1}$ : sole maize recorded significantly more grain weight per plant of maize the some other treatments like $\mathrm{T}_{5}$ : maize + green gram (2:1), $\mathrm{T}_{7}$ : maize + black gram (2:1), $\mathrm{T}_{8}$ : maize + green gram (2:2) and $\mathrm{T}_{10}$ : maize + black gram (2:2). Mandal et al. (2014) also recorded higher values of grain weight plant $^{-1}$ with sole maize in maizelegume intercropping system.

\section{Yield}

Grain yield of maize was significantly influenced by maize + legume intercropping system (Table 2 ).

Table 2: Yield of crops in summer maize-legume intercropping system

\begin{tabular}{|c|c|c|c|c|}
\hline \multirow[t]{2}{*}{ Treatments } & \multicolumn{2}{|c|}{$\begin{array}{l}\text { Grain yield kg } \\
\text { ha }^{-1}\end{array}$} & \multicolumn{2}{|c|}{$\begin{array}{l}\text { Stover yield kg } \\
\text { ha }^{-1}\end{array}$} \\
\hline & Maize & Legume & Maize & Legume \\
\hline $\mathrm{T}_{1}$ Sole Maize & 5669 & & 8164 & \\
\hline $\mathrm{T}_{2}$ Sole Green gram & & 618 & & 1196 \\
\hline $\mathrm{T}_{3}$ Sole Groundnut & & 1231 & & 2218 \\
\hline $\mathrm{T}_{4}$ Sole Black gram & & 956 & & 1294 \\
\hline $\begin{array}{l}T_{5} \text { Maize + green gram } \\
(2: 1)\end{array}$ & 4954 & 126 & 6275 & 242 \\
\hline $\begin{array}{l}\mathrm{T}_{6} \text { Maize + groundnut } \\
(2: 1)\end{array}$ & 5447 & 278 & 7456 & 502 \\
\hline $\begin{array}{l}T_{7} \text { Maize + black gram } \\
(2: 1)\end{array}$ & 5242 & 223 & 7094 & 281 \\
\hline $\begin{array}{l}\mathrm{T}_{8} \text { Maize + green gram } \\
(2: 2)\end{array}$ & 4977 & 244 & 6870 & 482 \\
\hline $\begin{array}{l}\mathrm{T}_{9} \text { Maize + groundnut } \\
(2: 2)\end{array}$ & 5610 & 522 & 7813 & 949 \\
\hline $\begin{array}{l}\mathrm{T}_{10} \text { Maize + black gram } \\
(2: 2)\end{array}$ & 5205 & 433 & 7116 & 618 \\
\hline SEm \pm & 95 & 8.6 & 124 & 16.4 \\
\hline $\mathrm{CD}(\mathrm{P}=0.05)$ & 293 & 25.9 & 383 & 49.2 \\
\hline CV (\%) & 5.4 & 5.7 & 5.1 & 5.7 \\
\hline
\end{tabular}

Highest grain yield was observed with $\mathrm{T}_{1}$ : sole maize (5668.5 $\mathrm{kg} \mathrm{ha}^{-1}$ ) and it was significantly superior to $\mathrm{T}_{5}$ : maize + green gram $(2: 1), \mathrm{T}_{7}$ : maize + black gram (2:1), $\mathrm{T}_{8}$ : maize + green gram (2:2), $\mathrm{T}_{10}$ : maize + black gram (2:2). However maize yield 
obtained in the treatment sole maize $\left(\mathrm{T}_{1}\right)$ was on par with $\mathrm{T}_{6}$ : maize + groundnut $(2: 1)$ and $\mathrm{T}_{9}$ : maize + groundnut (2:2). Earlier Pandey et al. (1999) observed similar results as sole maize produced more yield than intercropped maize and this result was probably due to inter species competition in intercropping. Stover yield of maize was influenced by maize + legume intercropping system. Maximum Stover yield of maize was recorded with $\mathrm{T}_{1}$ : sole maize (8164.2 $\left.\mathrm{kg} \mathrm{ha}^{-1}\right)$, however, it being statistically at par with $\mathrm{T}_{9}$ : maize + groundnut $(2: 2)$ produced significantly more straw yield than $\mathrm{T}_{5}$ : maize + green gram (2:1), $\mathrm{T}_{6}:$ maize + groundnut $(2: 1), \mathrm{T}_{7}$ : maize + black gram (2:1), $\mathrm{T}_{8}$ : maize + green gram (2:2) and $\mathrm{T}_{10}$ : maize + black gram (2:2). The results corroborate with the findings of Rajeshkumar et al. (2018).

\section{COMPETITIVE ABILITY}

\section{Maize Equivalent Yield}

Maize equivalent yield (MEY) was recorded to be higher in all of the cases of intercropping with respect to pure stand yield of maize. Maize yield + extra yield of legumes helped in increasing the maize equivalent yield in maize + legume intercropping system. Higher maize equivalent yield $(7609 \mathrm{~kg}$ ha$\left.{ }^{1}\right)$ was noted with $T_{9}$ : maize + groundnut (2:2 due to higher selling price of groundnut followed by $\mathrm{T}_{10}$ : maize + black gram (2:2). Moreover, sole maize produced grain yield of (5669 $\left.\mathrm{kg} \mathrm{ha}^{-1}\right)$, whereas $\mathrm{T}_{9}$ : maize + blackgram (2:2) recorded (7609 $\left.\mathrm{kg} \mathrm{ha}^{-1}\right)$ maize equivalent yield which is actually an increase of $34.2 \%$ enhancement of productivity. The results are in conformity with the findings of Pathak and singh (2008) and Nandan et al. (2013).

\section{Relative yield total (RYT)}

Relative yield total (RYT) is the sum of the relative yields (total biomass) of the species in the mixture and is expressed as the ratio of the yield of a species in the mixture to its yield in monoculture (Anders et al. 1996). Values greater than unity indicate partial complementarity among the species. In the study, among different intercrop combinations studied, $\mathrm{T}_{9}$ : maize + blackgram (2:2) recorded the maximum RYT (1.47) and it was followed by the treatment $\mathrm{T}_{10}$ : maize + black gram at 2:2 row proportion. The higher RYT value with above treatments was probably made possible by the contribution of the legume to the environment of the maize via nitrogen fixation (Baghdadi et al. 2016).

\section{Monetary advantage (MA)}

Monetary advantages were varied markedly by different intercropping systems. Intercropping paired row maize with two rows of groundnut $\left(\mathrm{T}_{9}\right)$ recorded the higher monetary advantage (₹ $42,002 \mathrm{ha}^{-1}$ ) and it was followed by intercropping of paired row maize with two rows of blackgram $\left(\mathrm{T}_{10}\right)$ in this study. All intercropping combinations of maize and legumes registered monetary advantage and this was probably due to adoption of additive series of intercropping in which was comprised of normal population of maize and additional legumes (Kheroar and Patra 2013).

\section{Area Time Equivalent Ratio (ATER)}

ATER was more than unity in all the treatments except $T_{5}$ : maize + green gram (2:1) clearly indicated efficient use of area and time by the intercrops. The lowest ATER values as well as less than unity value was obtained with $\mathrm{T}_{5}$ : maize + green gram $(2: 1)$ and it clearly indicated inefficient biological efficiency of such crop mixture probably due to competitive factors. Intercropping maize and legumes with the treatments $\mathrm{T}_{5^{\prime}}, \mathrm{T}_{6^{\prime}} \mathrm{T}_{7}, \mathrm{~T}_{8^{\prime}}, \mathrm{T}_{9^{\prime}}$ and $\mathrm{T}_{10}$ recorded

Table 3: Competition functions of summer maize-legume intercropping system

\begin{tabular}{|c|c|c|c|c|c|c|}
\hline \multirow[b]{2}{*}{ Intercrop combinations } & \multicolumn{3}{|c|}{ Maize equivalent yield $\left(\mathrm{kg} \mathrm{ha}^{-1}\right)$} & \multirow{2}{*}{$\begin{array}{l}\text { Relative } \\
\text { yield total } \\
\text { (RYT) }\end{array}$} & \multirow{2}{*}{$\begin{array}{l}\text { Area time } \\
\text { equivalent } \\
\text { ratio(ATER) }\end{array}$} & \multirow{2}{*}{$\begin{array}{l}\text { Monetary } \\
\text { advantage } \\
₹ \text { ha }^{-1}\end{array}$} \\
\hline & Maize & $\begin{array}{l}\text { Legume converted } \\
\text { into maize }\end{array}$ & $\begin{array}{l}\text { Total maize } \\
\text { equivalent yield }\end{array}$ & & & \\
\hline $\mathrm{T}_{5}$ Maize + green gram (2:1) & 4954 & 671 & 5625 & 1.07 & 0.93 & 27673 \\
\hline $\mathrm{T}_{6}$ Maize + groundnut $(2: 1)$ & 5448 & 1067 & 6515 & 1.19 & 1.13 & 35960 \\
\hline $\mathrm{T}_{7}$ Maize + black gram (2:1) & 5242 & 876 & 6118 & 1.15 & 1.03 & 33767 \\
\hline $\mathrm{T}_{8}$ Maize + green gram (2:2) & 4977 & 1299 & 6276 & 1.27 & 1.04 & 30123 \\
\hline $\mathrm{T}_{9}$ Maize + groundnut (2:2) & 5610 & 1999 & 7609 & 1.47 & 1.70 & 42002 \\
\hline $\mathrm{T}_{10}$ Maize + black gram (2:2) & 5204 & 1697 & 6902 & 1.37 & 1.17 & 37273 \\
\hline
\end{tabular}


ATER values slightly higher than unity indicating marginal yield advantages from these intercropping systems. The results corroborate the findings of Solanki et al. (2011) and Khan et al. (2018).

Table 4: Economics of summer maize-legume intercropping system

\begin{tabular}{lcccc}
\hline & \multicolumn{3}{c}{ Rupees ha-1 $^{-1}$} & \\
\cline { 2 - 4 } Treatments & $\begin{array}{l}\text { Cost of cul- } \\
\text { tivation }\end{array}$ & $\begin{array}{l}\text { Gross } \\
\text { return }\end{array}$ & $\begin{array}{l}\text { Net } \\
\text { return }\end{array}$ & B:C \\
\hline $\mathrm{T}_{1}$ Sole Maize & 37200 & 70522 & 33322 & 0.90 \\
$\mathrm{~T}_{2}$ Sole greengram & 26200 & 41584 & 15384 & 0.59 \\
$\mathrm{~T}_{3}$ Sole groundnut & 39200 & 59644 & 20444 & 0.52 \\
$\mathrm{~T}_{4}$ Sole blackgram & 24100 & 46927 & 22827 & 0.95 \\
$\mathrm{~T}_{5}$ Maize + green & 39866 & 70678 & 30812 & 0.77 \\
gram (2:1) & & & & \\
$\begin{array}{l}\mathrm{T}_{6} \text { Maize + groundnut } \\
(2: 1)\end{array}$ & 42533 & 81652 & 39119 & 0.92 \\
$\begin{array}{l}\mathrm{T}_{7} \text { Maize + black gram } \\
(2: 1)\end{array}$ & 39166 & 76551 & 37385 & 0.95 \\
$\mathrm{~T}_{8}$ Maize + green & & & & \\
$\begin{array}{l}\text { gram (2:2) } \\
\mathrm{T}_{9} \text { Maize + groundnut } \\
(2: 2)\end{array}$ & 42532 & 79160 & 36628 & 0.86 \\
$\begin{array}{l}\mathrm{T}_{10} \text { Maize + black } \\
\text { gram (2:2) }\end{array}$ & 47866 & 95820 & 47954 & 1.00 \\
\hline
\end{tabular}

\section{Economics}

Maximum net returns of ₹ 47,954 ha $^{-1}$ was obtained with treatment $\mathrm{T}_{9}$ : maize + groundnut $(2: 2)$ and it was followed by the treatment T10: maize + blackgram (2:2) which resulted in net returns of ₹ $45,499 \mathrm{ha}^{-1}$. But in case of benefit-cost ratio, $\mathrm{T}_{10}$ : maize + blackgram (2:2) and $\mathrm{T}_{9}$ : maize + groundnut (2:2) intercropping proportions yielded the value of 1.11 and 1.00 respectively. However, sole maize registered net returns of ₹ 33,322 ha $^{-1}$ with a benefitcost ratio of 0.90 and it clearly indicated advantage of former intercropping systems.

\section{CONCLUSION}

In the additive series of intercropping, maize got its desired population as compared to pure stand; thus intercropped maize produced yields close to its pure stand and paired row geometry of planting provided enough scope to the intercropped legumes to express satisfactory productivity probably due to temporal and spatial complementary effect. Intercropping maize + groundnut at 2:2 ratio and maize with blackgram at 2:2 ratio registered higher net return and these intercropping systems can be chosen in south Odisha conditions during summer.

\section{REFERENCES}

Baghdadi, A., Halim, R.A., Othman, R., Yusof, M.M. and Atashgahi, A.R.M. 2016. Productivity, relative yield and plant growth of forage corn intercropped with soybean under different crop combination ratio, Legume Research, 39(4): 558-564.

Jan, R., Saxena, A., Jan, R., Khanday M. and Jan, R. 2016. Intercropping indices and yield attributes of maize and black cowpea under various planting patterns. The International Quarterly Journal of Life Science, 11(2): 01-07.

Khan, M.A.H., Sultana, N., Akter, N., Zaman, M.S. and Islam, M.R. 2018. Intercropping gardenpea (Pisium sativum) with Maize (Zea mays) at farmers field Bangladesh. Agril. Res., 43(4): 691-702.

Kheroar, S. and Patra, B.C. 2013. Advantages of MaizeLegume Intercropping Systems. Journal of Agricultural Science and Technology B 3: 733-744 earlier titles: Journal of Agricultural Science and Technology, ISSN 1939-1250.

Maitra, S., Samui, R.C., Roy, D.K. and Mondal, A.K. 2001. Effect of cotton based intercropping system under rainfed conditions in Sundarban region of West Bengal. Indian Agriculturist, 45(3-4): 157-162.

Mandal, M.K., Banerjee, M., Banerjee, H., Alipatra, A. and Malik, G.C. 2014 Productivity of maize (Zea mays) based intercropping system during kharif season under red and lateritic tract of West Bengal. The International Quarterly Journal of Life Science, 9(1): 31-35.

Mucheru, M.M., Pypers, P., Mugendi, D., Mugwe, J., Merckx, R. and Vanlauwe, B. 2010. A staggered maize-legume intercrop arrangement robustly increases crop yields and economic returns in the highlands of Central Kenya, Field Crops Research, 115(2) 132-139.

Nandam, B., Shara, B.C., Kumar, A. and Nager, K.C. 2013. Production potential of maize and mustard under different intercropping system in moisture deficit subtropical areas of Jammu and Kashmir, India. Legume Research, 36(5): 436-441.

Pandey, I.B., Bharati, V. and Mishra, S.S. 1999. Effect of maize (Zea mays)-based intercropping systems on maize yield and associated weeds under rainfed condition. Ind. J. Agron., 48(1): 30-33.

Pathak, K. and Singh, N.P. 2006. Genotypic compatibility and planting pattern in urdbean and maize intercropping system. Ind. J. Pulses Res., 19(1): 116-118.

Patra, B.C., Mandal, B.K. and Padhi, A.L. 2000. Production potential of winter maize (Zea mays) based intercropping systems, Indian Journal of Agricultural Sciences, 70(4): 203-206.

Rajeshkumar, A., Venkataraman, N.S. and Ramadass, S. 2018. Integrated weed management in maize-based intercropping systems. Indian Journal of Weed Science, 50(1): 79-81. 
P. Manasa et al.

Saleem, R., Ahmed, Z.I., Ashraf, M., Arif, M., Malik, M.A., Munir, M. and Khan, M.A. 2011. Response of maizelegume intercropping system to different fertility sources under rainfed conditions, Sarhad J. Agric., 27(4).

Solanki, N.S., Dilip Singh. and Sumeriya, H.K. 2011. Resources utilization in maize (Zea mays) - based intercropping system under rainfed condition. Indian Journal of Agricultural Sciences, 81(6): 511-515.
Willey, R.W. 1979. Intercropping-Its importance and research needs: Part 1, Competition and yield advantages, Field Crop Abstract, 32(1): 1-10. 